\title{
Prolínání mocenských diskursů v týdeníku Učitelské noviny: sociální inkluze romských žáků $\mathrm{v}$ českém školství ${ }^{1}$
}

\author{
Dušan Klapko \\ Masarykova univerzita, Pedagogická fakulta, Katedra sociální pedagogiky
}

Redakci zasláno 12. 2. 2016 / upravená verze obdržena 28. 5. 2016 /

k uveřejnění přijato 6. 6. 2016

\begin{abstract}
Abstrakt: Cílem této výzkumné stati je analýza výpovědí o edukaci romských žáků jako žáků ze sociálně znevýhodněného prostředí, resp. žáků se specifickými vzdělávacími potřebami. Analýza výpovědí je zaměřena na diskursy utvářející školskou realitu z pohledu týdeníku Učitelské noviny. Výklad je zasazen do kontextu novely školského zákona, zabývajícího se sociální inkluzí. Pro metodologické účely byly použity nástroje diskursivní analýzy. V našem výzkumu jsme dospěli k analýze diskursivních pozic mluvčích, $\mathrm{k}$ výčtu mocenských diskursů, k popisu konstrukcí sociálně znevýhodněného prostředí romských žáků a k analýze strategií konstrukcí sociální reality z pohledu mluvčích.
\end{abstract}

Klíčová slova: mocenský diskurs, romský žák, ZŠ praktická, sociální inkluze, diskursivní analýza

Problematika sociální inkluze v českém školství nabrala na významu po přijetí novely školského zákona poslaneckou sněmovnou. Novela se týká zejména vzdělávání dětí, žáků a studentů se speciálními vzdělávacími potřebami (§ 16,16a,16b) a bude zavedena 1. 9. 2016. Místo žáka se sociálním či zdravotním znevýhodněním nebo zdravotním postižením novela zavádí pojem žák se speciálními vzdělávacími potřebami (dále SVP), který bude potřebovat úpravy podmínek vzdělávání pomocí podpůrných opatření. Tímto krokem se předpokládá posílení vize českého školství na cestě k rovnému přístupu a k inkluzi žáků se SVP mezi ostatní žáky na běžných školách. Spouštěčem novely se nejspíš staly zahraniční kritiky zástupců nadnárodních organizací (např́lklad Amnesty International), které upozornily na vysoký počet romských žáků v ZŠ praktických, a rovněž výroky štrasburského soudu v př́ípadu

1 Tato odborná stat' vznikla v rámci projektu GA ČR Konstrukce vzdělávání žáka ze sociálně znevýhodněného prostředí z pohledu tří světů jeho reálného žití (GP13-24036P). 
D. H. z roku 2007. Poněvadž bývá sémanticky zaměňován proces integrace žáků s inkluzí žáků, dovolíme si uvést následující citaci:

Inkluzívní vzdělávání má své principy, kterými se liší od vzdělávání dětí se znevýhodněním v běžných školách formou integrace. Předmětem snahy zúčastněných není pouze umístění znevýhodněného dítěte do běžné školy, ale spíše přizpůsobení školy potřebám dítěte. Důraz je kladen na kvalitu vzdělávání a zdůrazňuje prospěch pro obě strany. ${ }^{2}$

Názory na realizaci sociální inkluze v českém školství se vcelku výrazně liší. Jedním z důvodů jsou různé zdroje východisek v podobě závazných dokumentů (školský zákon, RVP ZV LMP, RVP ZV, Antidiskriminační zákon, Akční plán inkluzivního vzdělávání, Systémová podpora inkluzivního vzdělávání, klasifikace nemocí podle WHO, Katalog podpůrných opatření, Úmluva o právech dítěte ad.) a s nimi spojených institucí (MŠMT, Úřad veřejného ochránce práv - ombudsman, Rada vlády pro záležitosti romské menšiny, Liga lidských práv, Amnesty International, Evropská rada Romů, Open Society Justice Initiative, Rada Evropy, Evropská unie, Evropské centrum pro práva Romů, Nadace Open Society, Asociace speciálních pedagogů ČR, Asociace ředitelů ZŠ, Asociace logopedů ve školství, Asociace pracovníků SPC, Asociace psychologických pracovníků ad.), př́ípadně i představy jednotlivých aktérů (zvláště speciálních pedagogů, poradenských psychologů, sociálních pedagogů či zástupců neziskového sektoru nebo vládních úředníků). Důležitou roli hraje i způsob aplikace podpůrných opatření na žáky s různým typem postižení $\mathrm{v}$ podmínkách současného školství. Na relativně neutěšeném stavu dosaženého vzdělání romských žáků se dlouhodobě promítá faktor vzdělanostní reprodukce (Katrňák, 2004; Vojtíšková et al., 2011), jímž podle našeho názoru dochází $\mathrm{k}$ udržení sociální podřazenosti Romů, případně romských žáků. Dle četných výzkumů (Katrňák, 2003; Navrátil, 2003; Gabal, Čada, \& Snopek, 2008; Homoláč, 2009; Němec, 2010; Gulová, 2010; Šotolová, 2011; Fónadová, 2014 ad.), které se zaměřily na popis sociálního znevýhodnění Romů nebo na edukaci romských žáků, se významně podílejí i další faktory, zejména odlišné jazykové kódy, sociální kompetence, specifické sociální prekoncepty a hodnoty rodinné socializace, nízké vzdělanostní aspirace, úroveň sociálního zázemí, postavení romské ženy v rodině aj.

V naší výzkumné stati se zaměříme na problematiku edukace romských žáků z pohledu prolínání mocenských diskursů v tématu připravované sociální

2 Dostupné z http://www.inkluze.cz/inkluzivni-vzdelavani/inkluzivni-vzdelavani 
inkluze v českém školství. Zmapujeme výpovědní prostor utvářející konstrukci romský žák jako žák ze sociálně znevýhodněného prostředí, resp. žák se SVP. Vycházet budeme z mediálních konstrukcí odborného školského diskursu ke konkrétním dopadům sociální inkluze. Jádro sdělení tvoří popisy konstrukcí romského žáka, jež byly produkované zástupci jednotlivých institucí. Chceme se tak zabývat analýzou výpovědí v kontextu institucionální diverzity. Institucionální diverzitu zastupují zejména učitelé a vychovatelé v ústavní péči, ale i představitelé neziskových organizací, profesních sdružení nebo zástupci Ministerstva školství, mládeže a tělovýchovy. Jmenované mluvčí spojuje agenda konkrétních politických, vzdělávacích či kulturně-společenských témat, kterými se utváří vzájemně se prolínající sít diskursů o edukaci romského žáka. Předpokládáme, že pomocí diskursivní analýzy dokážeme pojmenovat a vysvětlit některé faktory konstruující status romský žák jako žák ze sociálně znevýhodněného prostředí, př́ípadně žák s LMP (lehkým mentálním postižením), či s SVP. Aktuální polemika mezi zastánci a odpůrci realizace sociální inkluze $v$ českém školství je $v$ našem výzkumu nahlížena optikou procesu přeřazování romských žáků do či ze ZŠ praktických, resp. jejich setrvání v běžných ZŠ.

Ačkoli se zaměřujeme prioritně na pedagogický a sociálněpedagogický diskurs, je zřejmé, že problematika má interdisciplinární přesah do oblastí sociální (vzdělávací) politiky, sociální antropologie, sociální geografie, sociologie prostoru a času, gender studies a dalších vědních disciplín a oborů. Výsek reality produkování diskursů o romském žákovi na úrovni jednoho periodika pochopitelně není vyčerpávající. Záběr našeho analytického materiálu má relativně úzký rámec v současné mediální realitě. Důvodem volby tohoto zdroje bylo kritérium hromadné dosažitelnosti (texty jsou dostupné na internetu) a kritérium specifičnosti (cílenosti) témat. Jsme si vědomi skutečnosti, že do debaty o vzdělávání romských dětí zasahují i další odborné časopisy, monografie, dokumenty, produkce četných nadnárodních a neziskových organizací atd. 


\section{Metodologie výzkumu ${ }^{3}$}

Pro náš výzkum byla zvolena sociologickovědní diskursivní analýza ${ }^{4}$ podle typologie R. Kellera (2007). Námi realizovanou diskursivní analýzu chápeme jako analýzu zdrojů diskursu a analýzu používání diskursu. Analýza zdrojů diskursu sleduje mocenské působení institucí a závazných dokumentů v sociálním jednání lidí v rámci kulturně-společenské situovanosti. Analýza používání diskursu se zaměřuje na výpovědi aktérů usilujících o jazykové ( $v$ našem případě tištěné) prosazení svých záměrů. Dominanci diskursů nad jednáním člověka definoval Foucault: „... lidé vědí, co dělají; často vědí, proč dělají to, co dělají; ale to, co neví, je co způsobuje to, co dělají." (cit. podle Dreyfus, Rabinow, \& Foucault, 2002, s. 187). Pro analýzu zdrojů diskursu a pro analýzu používání diskursu jsme si potřebovali vymezit tzv. diskursivní pramen. Diskursivní pramen představuje široké pole názorů v rámci společného tématu, které se různě prolínají, podporují či vyvracejí. V našem př́ipadě se jedná o společné téma možností a dopadů sociální inkluze, zejména ve spojitosti s edukací romských žáků. Diskursivní pramen se projevuje v podobě konkrétních prohlášení na povrchu textů (srov. Foucault, 2002), je složený z tzv. diskursivních fragmentů, které zastupují vždy a pouze jediné podtéma, například průzkum ombudsmana. Arénu, kde různé diskursy soupeří o zvýznamňování fenoménu sociální reality, nazýváme diskursivní pole. Pro charakteristiku diskursivních pramenů a fragmentů jsme zvolili jako diskursivní pole týdeník Učitelské noviny (dále UN). Při výběru cílového zdroje našeho výzkumu jsme vycházeli z kritéria veřejně dostupných pravidelně editovaných písemných příspěvků. Logicky padla volba na elektronická média, konkrétně na sektor novin. Výběr textů se týkal pětiletého kontinuální období (2010-2014), pomocí něhož můžeme sledovat distribuci témat a působení mocenských diskursů $\mathrm{v}$ čase. $\mathrm{V}$ této časové periodě jsme $\mathrm{z}$ archivu UN vybrali texty pojednávající o problematice romských žáků a o sociální

Pro zájemce četby o teoretickém ukotvení diskursivní analýzy v pedagogickém výzkumu odkazujeme na kapitolu v kolektivní monografii Výzkumné metody v pedagogické praxi (Gulová \& Šíp, 2013).

4 Vzhledem k faktu, že v sociálních vědách není využití diskursivní analýzy v ČR rozšířeným metodologickým způsobem k vysvětlení sociální reality, uvádíme odkazy na některé publikace: Hoffmannová a Müllerová (2000), Röhrich (2008), Zábrodská (2009), Homoláč (2009), Šanderová a Šmídová (2009), Šmídová (2013), Klapko a kol. (2014), Jarkovská (2013), Jarkovská a kol. (2015). 
inkluzi. Celkem jsme v UN napočítali sedmdesát čtyři příspěvkư ${ }^{5}$, které se zmíněné problematice věnovaly. Ve výzkumné stati jsme se zaměřili pouze na analýzu a interpretaci dvou výběrových témat, která dle našeho názoru adekvátně reprezentují názory širokého spektra aktérů ovlivňujících edukaci romských žáků. ${ }^{6}$

V naší analýze jsme se částečně drželi Foucaultova třídění diskursu podle formativních pravidel (Keller, 2007). Jednalo se o formace témat, výpovědních modalit, pojmů, řečových strategií. Rovněž jsme se zaměřili na popis typických diskursivních fragmentů, jak je koncipovali Jäger a Meyer (cit. podle Wodak \& Meyer, 2009). Tito autoři uvedli jako kritéria kontext, povrch textu, rétorické prostředky, ideologická vyjádření, diskursivní pozice.

Citované úryvky z článků v UN budou pro lepší přehlednost uvedeny menším písmem. $\mathrm{V}$ analýze úryvků budeme aplikovat následující značení:

- (myšlen rozsudek) - text v kurzívě vložený do závorek značí kontextovou doplňující informaci autora této výzkumné stati (nikoli citaci autora článku v UN);

- (PPP, školy) - text vložený do závorek bez kurzívy značí informaci autora článku v UN;

5 Jednotlivé články v UN v daném diskursivním prameni jsme kategorizovali podle obsahu sdělení. Vyšla nám následující frekvenční statistika (čísla v závorkách znamenají počet článků v UN): problémy s udržením asistentů pedagoga (2), polemika nad diagnostickými testy (5), kritika vlivu neziskových organizací (8), obhajoba činnosti neziskových organizací (1), kritika činnosti MŠMT (12), obhajoba činnosti MŠMT (4), spory s ombudsmanem (4), fungující inkluze v praxi (13), argumenty proti úplné inkluzi (9), názory Asociace speciálních pedagogů (5), analýza dokumentů (10), problém zázemí romských rodin (1). Pro diskursivní účinek článků v UN je důležité analyzovat i rubriky, ve kterých se texty námi vybraného diskursivního pramene objevovaly. Struktura UN se skládá z relativně velkého množství rubrik, například Komentáře, Publicistika, Téma UN, Zrcadlo praxe, Jak to vidí, Odborníci radí, Profil, Ohlasy, Dopisy ad. Většina textů našeho diskursivního pramene byla prezentována v rubrikách Publicistika a Zrcadlo praxe.

6 Pro úplnost dodejme, že v roce 2015 došlo v UN k rapidnímu nárůstu příspěvků o sociální inkluzi (zvláště komentáře k paragrafu 16), a to v souvislosti s přijatou novelou školského zákona, která vstoupí v platnost 1. 9. 2016. Obsahem příspěvků v roce 2015 byla zejména kritika vůči rušení př́lohy RVP ZV LMP a následnému předpokladu rušení ZŠ praktických. Kritika se tak ve většině případů orientovala na očekávaný úpadek vzdělávání dětí diagnostikovaných $\mathrm{v}$ hraničním pásmu lehkého mentálního postižení (LMP). V roce 2015 texty zaměřené výhradně na edukaci romských dětí v ZŠ praktických tvořily spíše dodatek k záměru realizovat sociální inkluzi žáků s LMP. 
- ... - tři tečky značí vynechaný text ze zkoumaného periodika za účelem vystižení významu výpovědi nebo redukce nadměrného textu v citaci;

- $\quad \mathrm{v}$ duchu českých tradic - podtržený text upozorňuje na důležité slovní výrazy, které zabarvují význam výpovědí.

Pomocí vybraných metodologických nástrojů7 diskursivní analýzy se pokusíme charakterizovat diskursivní pozici týdeníku UN. Výsledkem výzkumu bude interpretace odborného školského diskursu o edukaci romských žáků ze sociálně znevýhodněného prostředí, či romských žáků se SVP v kontextu zaváděných principů sociální inkluze v českém školství. Vzhledem k omezenému limitu stran pro popis našeho výzkumného šetření musíme čtenáře upozornit, že analytickou fázi diskursivní analýzy předvedeme pouze ve vybraných krátkých replikách mluvčích. Pro zájemce o podrobnější verzi aplikovaných nástrojů diskursivní analýzy odkazujeme na kolektivní monografii Výzkumný exkurz do diskursů o Romech (Klapko et al., 2014).

Nyní si položíme výzkumné otázky:

- Kdo je legitimní mluvčí? Z jakého institucionálního místa bylo hovořeno? Jakou diskursivní pozici mluvčí zastává?

- Jaké jsou verze objektivizovaného sociálního vědění o konstruktu sociálně znevýhodněný žák a jaké charakteristiky a typizace má edukace romského žáka podle názoru odborníků?

- Jak mluvčí obhajují (jakými diskursivními praktikami) své postoje a jakým způsobem charakterizují opoziční aktéry?

\section{$2 \quad$ Ukázky analyzovaných článků z UN}

V analyzovaných článcích jsme se zaměřili na dialogické sítě (Nekvapil \& Leudar, 2002). Dialogická sít' je formou masmediální komunikace, ve které jednotliví mluvčí na sebe nebo na téma reagují v různém prostoru a čase. Jedná se o tzv. jednání na dálku (Thompson, 2004). Důležitou charakteristikou dialogické sítě je aspekt zmnožení, pomocí nějž se výpovědi (repliky) distribuují k široké veřejnosti, a tím ovlivňují veřejné mínění. Sama organizace výpovědí má systém strukturních jednotek, které zpravidla slouží

7 Jako metodologické nástroje tř́ídění výzkumných dat jsme zvolili: kategorizační členskou analýzu (Sacks, 1992; Nekvapil, 1999-2000), interpretační repertoáry (Potter \& Wetherell, 2004), binární opozice (Zábrodská, 2009), modi operandi (Thompson, 1990). 
k prosazení vlastních názorů a získání příznivců z řad anonymních čtenářů. Výzkumný materiál jsme roztřídili podle námi pojmenovaných témat do dvou diskursivních fragmentů: Souboj rivalů o regulaci vzdělávání romského žáka (dva články v UN) a Průzkum ombudsmana ČR a Kanceláře ochránce lidských práv (tř̆i články v UN).

2.1 Výběr analyzovaných článků podle tématu Souboj rivalů o regulaci vzdělávání romského žáka

- Doporučení Amnesty International české vládě (6/2010);

- Ředitelé: speciální školství se stalo politickým tématem (25/2010)

Doporučení Amnesty International české vládě (6/2010)

V první části článku jsou popsány hlavní požadavky Amnesty International na českou vládu, zejména na MŠMT v oblasti problému segregace romských dětí v ČR.

Česká vláda musí segregaci romských dětí ve vzdělávání řešit systematicky... zejména Ministerstvo školství, by měly s okamžitou platností přijmout a uvést v obecnou známost rozhodný politický závazek vymýtit a ukončit segregaci ve školství... zejména Ministerstvo školství, by měly uvalit moratorium na umistování dětí do škol a tříd pro děti s „lehkým mentálním postižením“.

Slovník požadavků Amnesty International spadá do formy komunikace, již lze označit jako nátlakové vyjednávání. Oslovená česká vláda „musí řešit“, „vymýtit", „ukončit segregaci“, „uvalit moratorium“, a to rozhodně a okamžitě. Ráznost požadavků vytváří dojem vysoké aktuální míry diskriminace romských dětí. Lze předpokládat, že na jednu stranu vláda na tento nátlak bude neprodleně reagovat, nicméně na druhou stranu mohou zmíněné př́ikazy vzbudit nesouhlas u pracovníků, kteří se věnují edukaci romských žáků. Kritické a jednostranné zhodnocení stavu edukace romských žáků v ČR a s tím spojený tlak na českou vládu vytváří mocensky nadřazenou pozici Amnesty International jako nadnárodní instituce.

Po předložení požadavků byly ve zprávě vyjmenovány mechanismy podporující naplnění stanovených cílů: 
... prioritou bude zajistit opětovnou integraci těchto dětí do běžných základních škol... Opatření nutná pro takovou podporu zahrnují např́klad bezplatné školní vzdělávání v integrovaných mateřských školách pro děti ze sociálně znevýhodňujícího prostředí a poskytování bezplatné dopravy do předškolních tříd... je potřeba zvýšit počet asistentů pedagoga ve všech běžných základních školách.

Formulace „zajistit opětovnou integraci“ je latentní kritikou současné separace romských žáků v ČR. Tím, že je takový soud zobecněný na celou romskou populaci žáků, dochází de facto k obvinění celého školského systému na úrovni strukturální nerovnosti. Strategie zobecnění verdiktivu (rozsudku) podporuje maximalizaci nátlaku ke změně. Důvodem je snaha získat co nejlepší výchozí pozici k prosazení požadavků. Tyto požadavky s velkou pravděpodobností vzbudí polemiku, poněvadž se týkají nutnosti bezplatných služeb pro romské žáky a navíc investice zvláštních finančních fondů z kapes daňových poplatníků. Diskurs dodržování sociální spravedlnosti se zde střetává s nevysloveným diskursem rentability takto vynaložených prostředků, resp. s diskursem sociální odpovědnosti občanů a s diskursem odborných pedagogů. Daňoví poplatníci mohou nesouhlasit, protože romská komunita je v české společnosti stereotypně generalizována jako pobírač sociálních dávek, a tudíž neplatič daní.

Vyústěním požadavků Amnesty International byla konkrétně formulovaná výzva ke změně definice dítěte ze sociálně znevýhodněného prostředí na úrovni legislativy:

Novelizovat školský zákon... tak, aby obsahovala jasnou a objektivní definici kategorie dětí ze „sociálně znevýhodňujícího prostředí“. Tento termín by se měl používat pouze pro identifikaci dětí pro krátkodobá zvláštní opatření... Za žádných okolností nesmí toto kritérium vést $\mathrm{k}$ tomu, že bude s dítětem automaticky zacházeno jako s jedincem s „lehkým mentálním postižením“ a že bude umístěno do oddělené třídy nebo školy určené pro děti s postižením.

Samotné jádro stížnosti Amnesty International proti segregaci romských dětí jako dětí s mentálním postižením se zakládá nikoli na neodborné práci pedagogů, případně na záměrné rasové diskriminaci ze strany neromského obyvatelstva. Jádrem stížnosti je nejasná definice konstruktu žák ze sociálně znevýhodněného prostředí a spojování mentálního postižení s etnickým původem. Návrh řešení spočívá v relativně lehkém doporučení pro „krátkodobá zvláštní opatření" u dětí identifikovaných jako sociálně znevýhodněné. 
Přesné vysvětlení zmíněných opatření lze dedukovat z předchozího úryvku. Základní opatření proti segregaci romských žáků tak spočívá v rozlišení dítěte s mentálním postižením a dítěte ze sociálně znevýhodněného prostředí, které $\mathrm{z}$ nedostatku podnětů $\mathrm{v}$ rodinné socializaci působí mentálně opožděně. Požadavky Amnesty International byly předloženy co možno nejjednoznačněji, což dokumentují výrazy „jasnou a objektivní“, „pouze pro krátkodobá zvláštní opatření", „za žádných okolností nesmí“. Tento způsob předložení požadavků má formu právnického (zákonného) textu, vylučujícího či omezujícího dvojsmyslné výklady.

Interpretačním repertoárem ${ }^{8}$ Amnesty International je podle našeho názoru tato výpověd:

- Neprodleně oddělte spojování a zaměňování žáka s lehkým mentálním postižením se žákem ze sociálně znevýhodněného prostředí, je to diskriminace!

Ředitelé: speciální školství se stalo politickým tématem (25/2010)

$\mathrm{Na}$ kritiky představitelů Amnesty International vůči českému školskému systému reagovalo $\mathrm{v}$ UN několik autorů. $\mathrm{V}$ této části vybíráme text ředitelů ZŠ praktických, které upravil Radmil Švancar. Struktura článku měla formu komentovaných připomínek ředitelů, které byly pravidelně předkládány v modu stížnost-argumentace-obhajoba. V námi zvolené první části citací se jednalo o konstrukci záměrného tlaku neziskovek na vládu, aby zrušila údajnou segregaci romských dětí:

Speciální školství není ze strany MŠMT vůbec podporováno, odborná diskuze je nahrazena tlakem některých neziskových organizací, které jsou v odborných otázkách nekompetentní a neznalé hloubky celé problematiky... MŠMT nebouchne do stolu, nedistancuje se od těchto výkřiků. Připadáme si opuštění... Nebyl problém vysvětlit si své názory s inspektory, kteří své práci rozumějí, ale s lidmi z neziskovek se prostě domluvit nedalo... ze strany přizvaných osob z neziskových organizací nešlo o získání skutečného obrazu škol, ale o „dokázání si své pravdy“. Inspekce byla účelová, jejím úkolem bylo dokázat, že základní školy praktické pracují špatně, proto je nutné je redukovat - prý o $40 \%$ ! Přitom „neoprávněně zařazených" bylo zhruba $1 \%$.

8 Interpretační repertoáry suplují roli argumentačních „pravd“ mluvčích, kterými si obhajují svoje verze sociální reality. Zpravidla jsou tyto verze sociální reality nazírány jako produkt „common sense“, tj. běžného vědění či selského rozumu (Potter \& Wetherell, 2004). 
V textu jsou mocenské pozice rozloženy nerovnoměrně, MŠMT je obviněno z bázlivosti v jednání, neziskový sektor je konstruován jako nekompetentní útočník a zástupci tzv. speciálního školství se cítí opuštěni. Předpokládaná představa o spolupráci s MŠMT je považována za nerealizovanou prostřednictvím výrazů „není... vůbec podporováno“. Nicméně očekávání zastání ze strany MŠMT dokládá metafora „nebouchne do stolu“, „nedistancuje se“. Neoprávněnost postupu neziskového sektoru v očích ředitelů ZŠ praktických demonstrují výrazy „nekompetentní“, „neznalé hloubky“. Druhá výtka popisuje způsob jednání neziskovek, o čemž vypovídají výrazy „tlakem“, „výkřikü“, „se prostě domluvit nedalo“. Jednání neziskového sektoru je označeno jako účelová snaha obvinit edukační činnost ZŠ praktických a způsobit jejich redukci. K tomuto cíli byla použita relativizace „dokázání si své pravdy“. Konečně příznivci tzv. speciálního školství nalezli zastání u inspektorů. Díky této činnosti dostali inspektoři ústní ocenění v podobě profesní odbornosti „své práci rozumějí“. Přesvědčovací strategie autorů článku je založena na snaze o odbornou diskusi postavenou na přesvědčivých statistických datech. Mluva čísel v poměru $40 \%$ : 1\% má doložit oprávněnost názoru zástupců speciálního školství.

Interpretačním repertoárem ředitelů ZŠ praktických je podle našeho názoru tato výpověd:

- Necouvejme před politickým tlakem neziskovek, jsou to pedagogičtí diletanti!

\subsection{Výběr analyzovaných článků podle tématu Průzkum ombudsmana}

- Radmil Švancar: Ty jsi Čech a ty jsi Rom, myslí si lidé od ombudsmana o žácích (7/2012);

- Jiř́í Pilař: Vizualizace Romů ombudsmanem (9/2012);

- Jiří Pilař: ČŠI zase přikazuje sčítat romské žáky (33/2013);

Obdobu volné nepřímé dialogické sítě ve formě fóra názorů můžeme doložit na článcích komentujících průzkum Úřadu ombudsmana ČR a Kanceláře ochránce lidských práv, v němž bylo cílem zjistit počet romských žáků na vylosovaných školách, na nichž je vyučováno podle RVP pro žáky s lehkým mentálním postižením. Závažnost problému dokládá skutečnost, že články v UN byly prezentovány v intervalu celého kalendářního roku. 
Radmil Švancar: Ty jsi Čech a ty jsi Rom, myslí si lidé od ombudsmana o žácích (7/2012)

Na zmíněný průzkum Úřadu ombudsmana ČR a Kanceláře ochránce lidských práv reagoval R. Švancar poměrně rozsáhlým článkem. V tomto článku poskládal komentáře dvou ředitelů vylosovaných ZŠ a obsah petice rodičů romských žáků na straně jedné a pracovníků Úřadu ombudsmana na straně druhé. Ředitel ZŠ Lidická v Brně Gordon Brei vystoupil proti zmíněnému průzkumu:

Vypadá to, že je to šetření konané na zakázku Ligy lidských práv... Škola bude pravděpodobně v době jejich návštěvy prázdná, protože jsem rodiče informoval předem a všichni petici podepsali. Jsem rád, protože chci naše děti ušetřit tohoto ponižování. Zato se sčitatelé potkají se členy petičního výboru.

Argumentace ředitele G. Breie byla legitimizací jeho rozhodnutí nepodpořit pravděpodobně („vypadá to“) zištně připravené výzkumné šetření („konané na zakázku“). Krokem legitimizace se stalo podepsání petice všemi (romskými) rodiči. Přesvědčení o správnosti svého rozhodnutí zdůraznil čtenářům článku tím, že se jedná o akt jednání v zájmu dobra dětí, které byly ušetřeny etnického ponižování. Odsudek vůči realizátorům průzkumu byl zformulován jako spravedlivá reakce síly v podobě střetu se členy petičního výboru („za to se potkají“).

Ředitelka ZŠ Dobrovského z Moravských Budějovic Miroslava Zvěřinová postrádala smysl rozlišování etnicity žáků, což předvedla konstrukcí citace jednoho z žáků:

Proč nás přijdou počítat, když vy nám říkáte, že vám na tom nezáleží, kdo je a kdo není Rom?

Rétorický efekt citovaného dotazu jednoho z žáků měl zvýznamnit odsuzující údiv nad postupem Úřadu ombudsmana. Údiv má odkazovat na absenci etiky průzkumu, poněvadž došlo k etnickému vyčleňování, čehož si všimli i samotní žáci. Anonymita žáka stvrzuje důležitost otázky a upozad'uje jeho konkrétní identitu. I tato skutečnost má svůj význam, který spočívá v předpokladu, že takto uvažuje mnoho žáků školy. Paradoxně tak došlo k situaci, kdy škola etnicitu žáků neřeší, čímž se chová inkluzivně, zatímco Úřad ombudsmana svým průzkumem rozdílnost etnicity stvrzuje. 
Vysvětlující výklad paní ředitelky korespondoval s postojem ředitele Breie. Její argumentační linie byla vedena z kolektivní pozice stmeleného tábora učitelů ZŠ praktických, kteří mají negativní zkušenost s neziskovým sektorem.

Těžko lze očekávat od speciálních pedagogů ZŠ praktických vstřícný postoj vůči jakémukoliv šetření ohledně etnicity žáků po více jak desetiletém agresivním útoku některých neziskových organizací proti našemu typu školy... učitelé praktických škol již nevěří, že by měl někdo zájem zjištovat pravý stav věcía hlavně vůli věci řešit na odborné úrovni ve prospěch dětí. $V$ posledních letech jsme pouze terčem politiků a právníků. Naší nadějí snad může být... by se mohlo prokázat, že v našich školách se nejedná o nerovný přístup ke vzdělávání z důvodů etnicity, tak jak je veřejnosti podsouváno.

Ředitelka M. Zvěřinová vcelku otevřeně předložila důvody nedůvěry tzv. speciálních pedagogů vůči neziskovému sektoru. Důvody členila podle zdroje regulace a způsobu jednání. $Z$ hlediska zdroje regulace vzdělávání romských žáků vytvořila binaritu tzv. speciální pedagogové-zástupci neziskovek. Z hlediska jednání ostře obvinila neziskový sektor z „desetiletého agresivního útoku“ a z tlaku politiků a právníků (,jsme pouze terčem“). Nucená obrana pracovníků speciálních škol tak vede k nedůvěře v rovině odborné i lidské. Pro udržení vlivu vlastního tábora konstruovala naději ve spravedlivé prokázání rovného př́istupu vůči romským dětem a zároveň povzdech nad praktikami mediálního mocenského diskursu ,jak je veřejnosti podsouváno“.

Druhá polovina článku R. Švancara byla věnována názorům pracovníků Úřadu ombudsmana. Rozhovor byl realizován se zástupkyní ombudsmana Varvařovského Jitkou Seitlovou a garantem projektu (průzkumu) Michalem Čermákem.

J. Seitlová předložila následující zdůvodnění realizace průzkumu:

... jsme neustále pod tlakem zahraničních institucí, které se zabývají lidskými právy... Indikátorem toho, zda k tomu (diskriminaci) dochází, je právě zastoupení žáků podle jednotlivých etnicit... Možná někde vznikla nějaká komunikační bariéra... Jsme ale přesvědčeni, že je všechno v pořádku. Průzkum by měl naopak sloužit tomu, abychom... pomohli udělat pořádek... A zdůrazňuje: Nechceme za každou cenu prokázat nějakou diskriminaci, z toho nás nepodezírejte.

J. Seitlová vyjádřila podporu realizace průzkumu. Vědoma si nesouhlasu zástupců praktických škol, pokusila se konfliktní téma zmírnit odkazem na „tlak zahraničních institucí", vznikem občasných, nikoli stálých komunikačních bariér („možná někde... nějaká“) a významem vypočítání indikátoru jako klíče 
k věcnému posouzení situace v českém školství. Činnost Úřadu ombudsmana tak diskursivně formovala do instituce, která chce pomoci „udělat pořádek“, a nikoli rozpoutat spor o diskriminaci. Důležitost tohoto cíle dokládají výrazy „zdůrazňuje“, „nechceme za každou cenu“, „nás nepodezírejte“.

Pro úplnost analýzy jazykového jednání všech aktérů ocitujeme výklad z petice romských rodičů:

... vyzýváme veřejného ochránce práv, aby přestal podporovat snahy o zrušení základních škol praktických. Podpořte naše snahy o znemožněnídalší diskriminace našich dětí tím, že nám bude diktováno, kde a jak je máme vzdělávat... Přejeme si, aby ZŠ praktické vzdělávaly naše děti ne jako mentálně retardované, ale jako děti $\mathrm{s}$ výukovými problémy. Důrazně se ohrazujeme proti zjištování národnosti našich dětí ve školách bez našeho vědomí... to porušuje naše právo na sebeurčení.

V petici je formulována výzva romských rodičů ombudsmanovi, který je jako představiteli státní instituce. $V$ obsahu výzvy se požaduje přepólování názoru o nutnosti rušit ZŠ praktické, ačkoli rušení těchto škol nebylo Úřadem ombudsmana požadováno. Zdrojem přesvědčení o konstrukci budoucího rušení ZŠ praktických byli spíše učitelé, v tomto př́ípadě ředitel G. Brei. Diskursivně se tak navodil stav faktického rušení ZŠ praktických, ačkoli požadavek Amnesty International (jako původce spuštěné kritiky) směřoval k převedení 40 \% romských žákủ do běžných škol kvůli vymýcení jejich segregace. $O$ rušení ZŠ praktických tak primárně nešlo, spíše o redukci stavu romských dětí na ZŠ praktických. Úřad ombudsmana si na základě zprávy Amnesty International dal za úkol věc výzkumně prošetřit. Paradoxně tak romští rodiče v petici žádali „znemožnění další diskriminace“ a zároveň setrvání svých dětí v ZŠ praktických. Zdůvodnění spočívalo v přenálepkování statusu romských žáků z „mentálně retardovaných“ na žáky „s výukovými problémy“. Obavy romských rodičů z údajného diktátu, „kde a jak je máme vzdělávat", vyplývaly ze zjištování etnicity „ve školách bez našeho vědomí“. Úřadu ombudsmana tak bylo nakonec oznámeno, že průzkumem porušuje „naše právo na sebeurčení". Petice romských rodičů čerpala zdroj své opodstatněnosti z historického odkazu vzniku národních států po první světové válce. $V$ petici se rovněž stvrdila fakticita diskriminace Romů v ČR.

Interpretačním repertoárem v článku Radmila Švancara je podle našeho názoru tato výpověd':

- Romský žák je v centru školského dění, ale rozhoduje se na politické rovině. 
Jiř́ Pilar̆: vizualizace Romů ombudsmanem (9/2012)

Na problém průzkumu etnicity na ZŠ praktických reagoval krátký půlstránkový text speciálního pedagoga Jiř́ho Pilaře. Tentýž autor zhruba po roce rozš̌riril své názory v reakci na činnost České školní inspekce (ČŠI). Pilařův výklad má formu filipiky. J. Pilař svůj nesouhlas s průzkumem Úřadu ombudsmana a ČŠI konstruoval jako kritiku nesmyslných kritérií určujících, kdo ze žáků patř́í k romskému etniku:

Při dotazech, jak jsou posuzovány děti ze smíšených manželství, „výzkumníci“... tvrdili, že Romem je pouze dítě tmavovlasé a jeho blondatý sourozenec nikoliv. A pokud je dítě madarských rodičů... často tmavovlasé, stane se... taky Romem... a čárkuií si v seznamech domnělé nebo skutečné Romy... chlubíce se, že „na třídu jim stačí šest až osm minut" (Čermák, UN č. 7/2012)... o to víc z jejich snahy čiší hloupost... svým pácháním dobra škodí, kudy chodí, a mohou být pro nás i zadarmo drazí...

Vysvětlení realizace průzkumu je ironizováno označením „výzkumníci“ v uvozovkách. Tito „výzkumníci“ rozpoznávají původ dítěte intuitivním odhadem, „čárkují si v seznamech domnělé... Romy“, „chlubíce se“ efektivností měření. Jako doklad neodbornosti autor článku citoval výpověd’ M. Čermáka o časové periodě získávání dat na jednu školní třídu. Zdroj argumentačního rámce mj. vyplývá z rozlišení mezi průzkumem a vědeckým výzkumem. $\mathrm{Na}$ jiném místě této výzkumné statě jsme uvedli poznámku, že pracovníci Úřadu ombudsmana (M. Čermák, J. Seitlová) nazvali svůj záměr oběma způsoby. Téma zjištování statistiky počtu romských dětí charakterizoval autor článku výrazy „z jejich snahy číší hloupost“, „pácháním dobra škodí, kudy chodí" a "mohou být pro nás i zadarmo drazí" (tento oxymóron je převzat). V závěru úryvku citací je nepř́ímo stvrzen fakt o politickém nátlaku, protože „nikoho nezajímá" porušování práva na ochranu osobních údajů, ačkoli o tom mediálně informoval Úřad na ochranu osobních údajů.

Jiří Pilař: ČŠI zase přikazuje sčítat romské žáky (33/2013)

Konstrukce J. Pilaře směřovala k obvinění nevládních organizací:

Nepředpokládám, že ČŠI chce zjištovat, kdo má mít jaká práva kvůli své etnické př́slušnosti. Spíš asi hledá cesty ( $\breve{C} \breve{S})$, jak získat informace pro nevládní organizace, které s ní úzce spolupracují, aby pak mohly do světa hlásat, jak se u nás porušují lidská práva, jak odpíráme plnohodnotné vzdělání našim romským dětem. Inu, je to již takový český folklór, že organizace žijící ze státních grantů pomlouvají svoji zemi v cizině. Nikoho nezajímá vyjádření Úřadu na ochranu osobních údajů v dané věci z 25. 9. 2012. 
V úryvku je fabulována školská realita do spekulace, jejíž podstatu tvoří úzká spolupráce ČŠI a nevládních organizací. Cílem této spolupráce má být pomlouvání poměrů v českém školství. Osobní zájmeno „našim“ plní úlohu ironizace př́íkladů diskriminace romských žáků. Tyto př́klady považuje autor za pomluvy a navíc ironizuje i skutečnost, že romští žáci touží po plnohodnotném vzdělání, které je jim odepřeno. Eufemizace rozhádané reality v problému edukace Romů „inu, je to již takový český folklór“ je následně vystř́ídána tvrdým obviněním, že „organizace žijící ze státních grantů pomlouvají svoji zemi“.

ČŠI se pokusila dokončit sčítání romských žáků obdobně jako Úřad ombudsmana. Za tento počin byla J. Pilařem kritizována:

ČŠI se opět „pochlapila“ a podruhé počítá romské žáky v ZŠ praktických. Odkazuje na plnění Akčního plánu opatření pro výkon rozsudku Evropského soudu... Jen na okraj - odborná veřejnost se s tímto materiálem nikdy neztotožnila. ČŠI úkoluje ředitele... Dokonce ředitele upozorňuje... že taková škola může být podrobena státní kontrole. Jsme ještě v postbolševické společnosti, anebo předpona post pozvolna mizí v mlze? Anebo že by to byl dopad salónního levicového aktivismu zástupců neziskovek?

Sčítací aktivita instituce ČŠI je autorem ironicky personifikována větou „se opět pochlapila“, přičemž doplňuje, že se odborná veřejnost s jejím výsledkem „nikdy neztotožnila“. Kromě toho ČŠI ředitele škol „úkoluje“ a „podrobuje státní kontrole“. Domnělý nátlak ze strany ČŠI je přirovnán k praktikám $\mathrm{v}$ totalitní společnosti. Autor se ironicky ujištuje, v jakéže to společnosti vlastně žijeme, když se dějí takové nátlaky? Kromě pejorativního označení „postbolševické společnosti“ (výraz nepřímo odkazuje k perzekučním praktikám stalinského režimu) se cílem kritiky stali zástupci neziskovek, člensky kategorizovaní do škatulky „salónního levicového aktivismu“.

Nyní se zaměříme na analýzu celkového shrnutí problému J. Pilařem:

Vzdělávání Romů v ČR je skutečně dlouhodobý problém, ale není dominantním tématem pro školy speciální, jak neodborníci mylně běžně uvádějí, ale školy běžného vzdělávacího proudu, které neumí dlouhodobě pracovat $s$ dětmi se speciálními vzdělávacími potřebami. A samozřejmě i pro pedagogické fakulty... Proč nejsou tomuto šetření podrobeny i běžné ZŠ, z nichž právě přichází impuls, že žák (patrněs $S P U$ ) na běžné vzdělávání nestačí? Proč jsou opět stavěny do pozice viníka školy (praktické)... Proč se nikde neakcentují závěry sledování Agentury EU pro základní práva (Úroveň vzdělání mají Romové v ČR nejvyššî)... z roku 2012? Že by se to někomu nehodilo do podnikatelského záměru (založení soukromých elitních škol)? 
Stanovisko J. Pilaře ospravedlňuje činnost ZŠ praktických, resp. funkčnost tzv. speciálního školství. Vzdělávání romských dětí považuje v ČR za problém, nicméně upřesňuje, že na vině jsou nedostatky odbornosti na straně běžných škol a pedagogických fakult. Zúžený kritický pohled na školy praktické vysvětlil jako běžný omyl neodborníků. Celkově se argumentační rétorika J. Pilaře opírala o expertní diskurs, čímž bylo možné relativně snadno vyvracet jakékoli kritické námitky o segregaci romských žáků. Prostřednictvím expertního diskursu pozicoval, kdo do vyvolené skupiny expertů patř́í, a kdo nikoli. Rétorické otázky v posledním uvedeném úryvku měly za úkol přenést pozornost čtenáře a tematiku z roviny edukační do roviny finančního profitu a práva regulovat, které se „někomu hodí do podnikatelského záměru“.

Interpretačním repertoárem Jiř́ího Pilaře je podle našeho názoru tato výpověd':

- Neziskové organizace se chovají diletantsky a zištně!

\section{Shrnutí}

Závěrečné shrnutí našeho výzkumného šetření jsme pojali jako odpovědi na výzkumné otázky. Dovolili jsme si interpretovat shrnutí ze všech analyzovaných článků o sociální inkluzi romských žáků v UN za období 2010-2014. ${ }^{9}$ $\mathrm{V}$ analyzovaných článcích UN jsme dospěli k následujícímu výčtu mocenských diskursů:

- diskurs inkluzivní (zástupci učitelů a ředitelů ZŠ praktických x zástupci neziskového sektoru);

- diskurs učitelský (speciální pedagogové x běžní učitelé);

- diskurs globalizační (nadnárodní instituce x české instituce);

- diskurs segregativní (školy romské x školy neromské);

- diskurs etnický (Romové x neromská populace);

- diskurs strukturální nerovnosti (konkrétní jednotlivec x institucionální systém);

- diskurs historizující (minulost x př́ítomnost).

9 Vzhledem k rozsahu analytického materiálu jsme v kap. 2 prezentovali pouze analýzu vybraných citací ze dvou diskursivních fragmentů. $\mathrm{V}$ kap. 3 bylo naší prioritou zodpovědět výzkumné otázky v kontextu zvoleného časového období 2010-2014, a proto vycházíme z analýzy všech 74 článků diskursivního pramene. 
Zmíněné diskursy působily na výpovědi jednotlivých mluvčích. Prolínání zmíněných diskursů do výpovědí mluvčích budeme interpretovat v kontextu odpovědí na následující výzkumné otázky:

(1) Kdo je legitimní mluvčí v UN? Z jakého institucionálního místa bylo hovořeno? Jakou diskursivní pozici mluvčí zastává?

Diskursivní pozice UN se jevila jako jednoznačně hájící zájmy učitelů ZŠ praktických, periodikem označených za tzv. speciální pedagogy. Redakci týdeníku tvoří šest pracovníků, kteří mají tematicky pokryté strukturní oblasti českého školství (jednotlivé stupně školské soustavy, ČŠI, evropské fondy, státní správa a samospráva, školská ekonomika, poradenství, speciální školy). Oblast edukace romských žáků, řazenou do speciálního školství, redaktorsky zajištuje zejména Radmil Švancar, kterého lze považovat za legitimního mluvčího týdeníku UN. Články zabývající se edukací romských žáků, resp. existenčními problémy ZŠ praktických, byly redakcí UN koncipovány převážně v kritickém vytýkacím modu. Jednalo se zpravidla o obvinění ze zištných praktik neziskového sektoru a nevládních organizací a ze slabosti MŠMT, které rozbíjí funkční model selektivního školství v ČR. Výběr zástupců škol (ředitelé, učitelé) a zástupců pedagogicko-psychologických poraden nebo členů školských asociací přispívajících do UN preferoval odpůrce změn úplné, ale i částečné sociální inkluze. Přístup k vyjádření byl poskytnut i kritizovaným neziskovým organizacím nebo zástupcům MŠMT. Forma těchto článků měla podobu dotazů „na tělo“, zpravidla pod patronací R. Švancara, který kromě pokládání dotazů vyjadřoval i vlastní stanoviska a kritické komentáře. Svými postřehy tak přesvědčoval čtenáře o adekvátnosti vlastního náhledu na zvolenou problematiku.

(2) Jaké jsou verze objektivizovaného sociálního vědění o konstruktu sociálně znevýhodněný žák a jaké charakteristiky a typizace má edukace romského žáka podle názoru odborníků?

V souvislosti s interpretací pojmu sociálně znevýhodněný žák zazněla ve sledovaných článcích UN poznámka o neujasněnosti významu tohoto pojmu. Výklad se tak orientoval spíše na konstrukci sociálně znevýhodněného rodinného prostředí a tím na členskou kategorizaci romských rodičů. Tato kategorizace byla vedena strategií symbolické konstrukce nazvané generalizace, čili hodnocení romských rodičů platilo obecně na všechny. Až na výjimky, kdy inkluzivní školy úspěšně spolupracují s romskými rodiči, byly ostatní články v případě charakterizace hodnot Romů skeptické s poukazem 
na nízkou prestiž vzdělání v jejich komunitě. Obsah článků kritizoval zanedbávající ranou péči romských rodičủ a tím znemožnění efektivní primární socializace jako základu pro úspěšné fungování romských dětí v běžných školách. Nízká hodnota vzdělání, zanedbávající péče rodičů a reprodukce špatných sociálních vzorů tak byly konstruovány jako příčina problému vzdělávání romských žáků. Zobecňující tendence na zanedbávající výchovnou péči v primární socializaci romských dětí stvrzovaly faktor vzdělanostní reprodukce a tím nemožnost dosáhnout výrazné změny. Část názorů v UN se $\mathrm{v}$ této problematice snažila komentovat klady a zápory požadavku uzákonit povinnou předškolní docházku romských dětí. Problém edukace romských žáků spočíval zejména $v$ typizovaném předpokladu jejich školního neúspěchu, resp. nezájmu o vzdělání. Další typizaci spatřujeme v konstrukci očekávaného průběhu sociální inkluze, která údajně dosáhne pouze integrace žáků. Tato integrace bude mít charakter spolužití (vedle sebe, nikoli spolu) ve školních lavicích. Mluvčí rezignovali na možnost reálného dosažení individuálního př́istupu k žákům a na efektivní diferenciaci kognitivní náročnosti výuky a hodnocení školních výsledků. Zároveň byla reforma zavádějící sociální inkluzi napadána z hlediska finanční nákladnosti, odborné nepřipravenosti a didaktické neúčelnosti.

Z pohledu odborníků, kam byli začleněni zástupci speciální pedagogiky, pedagogické psychologie a učitelé na ZŠ praktických, je nutné udržet (selektivní) dvoukolejní ráz českého školství v podobě tzv. běžných škol, speciálních škol a tzv. škol praktických. Tito aktéři obhajovali své stanovisko jako snahu vyhovět specifickým potřebám romských žáků (i přáním jejich rodičů), pro které mají ze své praxe adekvátní dovednosti. Spor o edukaci romských žáků se vedl v tématu diagnostiky lehkého mentálního postižení a jeho (automatického) spojování se sociálním znevýhodněním. Učitelé a ředitelé ZŠ praktických společně s pracovníky v pedagogicko-psychologických poradnách (PPP) důvěřují psychologickým diagnostickým testům a rovněž zdravému znalostnímu úsudku, který byl vytvořen na základě pozorování chování žáků. Problém potenciálního unáhleného přeřazování (zvláště romských) žáků do ZŠ praktických má být vyřešen přesunutím ohniska zájmu poradenských pracovníků na fázi aplikační, nikoli diagnostickou. Aplikační fáze má výhodu především svojí fluidní povahou, tedy možností procesuální změny stanoviska dle chování a studijního výkonu žáka. Lepší postavení aplikační fáze je potvrzeno i kompetentností pracovníků školských poradenských zařízení, kteří situaci v edukačním prostředí rozumí údajně lépe, než kolegové 
z jiných rezortů (například rezortu zdravotnictví). Opačný pohled na edukaci romských žáků zastával tábor nevládních a neziskových organizací, který byl v UN označen jako neodborný. Jeho představitelé podporovali reformní změnu v podobě úplné nebo alespoň částečné sociální inkluze, resp. odbourání romské diskriminace ve školách. Významným mezníkem byl rozsudek štrasburského soudu v případu ostravských Romů, kteří úspěšně žalovali ČR za diskriminaci (případ D. H. z roku 2007).

Podle názorů autorů ze speciálněpedagogického tábora došlo k přijetí (inkluzivní) novely školského zákona $\mathrm{v}$ roce $2015 \mathrm{v}$ důsledku aktivit neziskového sektoru brojících vůči (údajné) diskriminaci romských žáků. Zdrojem snah o inkluzivní změny v českém školství se staly kritiky zástupců nadnárodních organizací, zvláště Amnesty International, a některé průzkumy českých institucí, např́klad Úřadu veřejného ochránce práv (ombudsmana) anebo ČŠI. Proces přeřazování romských dětí do ZŠ praktických označili výše zmínění zástupci neziskového sektoru jako diskriminační. Výtka však nebyla vedena vůči diagnostickým testům, ale vůči rozhodování psychologických pracovníků, kteří údajně jednostranně interpretují výsledky na základě selektivních tendencí. Do tábora neodborníků byli redakcí UN diskursivně přiřazeni zástupci neziskových organizací i zástupci MŠMT. Představitelé MŠMT v článcích volili smíŕlivé stanovisko formou dementování extrémních intepretací speciálních pedagogů vůči tehdy připravované novele školského zákona.

(3) Jak mluvčí obhajují (jakými diskursivními praktikami) své postoje a jakým způsobem charakterizují opoziční aktéry?

K zodpovězení této otázky jsme aplikovali tzv. modi operandi ${ }^{10}$ (Thompson, 1990), kterými mluvčí ideologicky konstruovali své vidění sociální reality. Ve výčtu argumentací vybraných článků v UN se nejčastěji objevovaly následující ideologické modi operandi: legitimizace, unifikace, fragmentace. Méně častou formou modů operandi byla reifikace nebo zatajení.

Legitimizaci nejvíce charakterizovala strategie zobecňování skupinových identit či členských vlastností (Romové, neziskový sektor, speciální pedagogové), ale i vyznávání hodnot (spravedlnosti, rovnosti). Méně častou strategií

10 Modi operandi představují způsoby ideologického působení v řečových aktech za účelem vytváření dominance a moci. Jedná se o modi legitimizace, zatajování, sjednocování (neboli unifikace), rozdělování (neboli fragmentace) a reifikace. Tyto modi operandi jsou aplikovány pomocí strategií symbolické konstrukce výpovědí, kterými mluvčí mobilizují významy interakcí a objektů v sociálním světě. 
byla racionalizace navrhovaných postupů řešení, případně narativizace blízké budoucnosti. Legitimizace se tak pravidelně využívala:

- v kontextu prezentace či přesvědčování o správnosti a odbornosti preferovaných názorů;

- v kontextu odkazování se na závazné kurikulární, legislativní nebo morální dokumenty či kodexy;

- v kontextu životem osvědčených postupů, pravd a hodnocení.

Unifikaci (sjednocování) charakterizovala strategie symbolické jednoty, sdružující se na základě společného profesního prostoru, společných názorů na edukaci romských žáků nebo společných kritik vůči oponentům. Zajímavým projevem symbolické jednoty se stalo personifikování ČR. Zároveň se v článcích vyskytla i strategie standardizace ověřených metodik, jak vzdělávat romské žáky, př́padně jakým způsobem je ne-přeřazovat do ZŠ praktických. Unifikace se tak pravidelně využívala:

- v kontextu konstrukcí shromažd'ujících tzv. odborníky, resp. příznivce zastávaného řešení či názoru;

- v kontextu prosociálních úmyslů v rámci diskursu rovných příležitostí.

Fragmentace (rozdělování) byla velmi častým jevem téměř v každém citovaném úryvku. Mluvčí pomocí řečových aktů ${ }^{11}$ často předkládali stížnosti, obvinění, př́padně obhajoby. $V$ tomto modu se významně projevily strategie diferenciace a odstranění druhých, a to vyjmenováváním rozdílů, neshod, křivd či charakterových vlastností. $\mathrm{V}$ rámci binarit docházelo $\mathrm{k}$ jakostnímu hodnocení kategorie My jako znalci či morálně zdatní jedinci a kategorie Oni jako diletanti a morálně pokleslí jedinci. Fragmentace se tak pravidelně využívala:

- prostřednictvím binarit My - Oni, odborníci - diletanti, speciální pedagogové - ostatní edukační činovníci, zastánci inkluze - odpůrci inkluze, Romové - příslušníci neromské populace, školské instituce - neziskové instituce, kladné charakterové vlastnosti - záporné charakterové vlastnosti, domácí (přátelské) - cizí (nepřátelské).

11 Podle Austina (2000) se výpovědi stávají řečovým aktem, až když je přijmou adresáti. Každý řečový akt vyjádřený v určitém kontextu má ilokuční (tzn. sociální) sílu. Řečové akty jsou tak chápány jako způsoby konání. 
V reifikaci se jednalo o strategii naturalizace, která se používala k odhalování příčin školního neúspěchu romských dětí v běžných ZŠ. Naturalizací se romská odlišnost a neúspěch přirozeně zvýznamňovaly, a to ve vztahu ke vzdělání a výjimečně i k práci. Reifikace se tak pravidelně využívala:

- v kontextu životních hodnot romského etnika.

V modu zatajování se projevilo nejčastěji užívání metafor a ironické eufemizace zpravidla při konstrukcích př́íkladů nedostatečné odbornosti na straně zástupců neziskového sektoru a MŠMT. Konstrukce popisů tábora protivníků v problematice edukace romských dětí byla vedena častým užíváním jakostních hodnocení, původně vycházejících z binárního tř́dění osob a jevů. Opakovaným jevem byla degradace odborných pedagogických kvalit zástupců neziskového sektoru. Účel jejich činnosti byl spatřován v politickém i faktickém obohacování se na zveličování problému, který dle některých autorů článků nemá opodstatnění. Domnělé diletantské názory opozičníků byly připomínány zejména v konstrukcích poukazujících na nereálnost požadavku úplné sociální inkluze, $v$ údajné neznalosti práce s romskými dětmi, ve způsobech diagnostikování mentálního postižení žáků nebo ve slabé metodologické erudovanosti.

\section{Diskuse a závěr}

Tímto textem jsme se pokusili analyzovat výseky sociální reality, jaké prezentují vybrané články v týdeníku Učitelské noviny o tématu sociální inkluze a edukace romských žákủ v českém školství. Produkované vědění o edukaci romských žáků je tak nahlíženo z úhlu mocenského prolínání diskursů, kterými se utváří ideologické kolbiště mezi zastánci a odpůrci změn $\mathrm{v}$ českém školství.

Analytickou část naší výzkumné stati jsme zahájili tzv. dialogickou sítí mezi táborem neziskového sektoru a táborem speciálních pedagogů. Konkrétně jsme úvod konfliktu datovali do období vynesení rozsudku v př́ípadu D. H. štrasburského soudu (13. 11. 2007) a do kritik Amnesty International vůči (údajné) diskriminaci romských žáků v českém školství. Tato kritika spočívá $v$ jejich přeřazování do ZŠ praktických na základě etnicity a nálepky žáků ze sociálně znevýhodněného prostředí. Spor o přeřazování vysokého počtu romských dětí do ZŠ praktických se týká způsobu diagnostiky v pedagogicko-psychologických poradnách a v souhlasu romských rodičů s přeřazením, který nevládní organizace považují za důsledek strukturální 
nerovnosti. Školní neúspěšnost romských žáků v běžné škole se zpravidla vysvětluje/vysvětlovala poukazem na lehkou mentální dysfunkci romských žáků či na jejich rodinný background (žák ze sociálně znevýhodněného prostředí) a řeší/řešila doporučením $\mathrm{k}$ jejich přeřazení na ZŠ praktickou. Na straně protiargumentů se nacházejí zástupci tzv. speciálního školství, kteří podporují zachování selektivního charakteru vzdělávání žáků podle jejich postižení. Nicméně i oni souhlasí s možností aplikace principů inkluze, kde to podmínky dovolí. Vzdělávací program RVP ZV s přílohou LMP (lehké mentální postižení) považují za efektivní kurikulární dokument pro vzdělávání žáků diagnostikovaných jako žáků se specifickými vzdělávacími potřebami. Ve svých výpovědích kritizují neziskový sektor a vládní orgány za snahy zpolitizovat problém za účelem čerpání peněz z evropských strukturálních fondů a z jejich pedagogické nekompetentnosti. Zástupci speciálního školství se obávají zrušení faktické existence ZŠ praktických, dále ze školního neúspěchu a šikany žáků s diagnózou hraničního intelektu po přestupu na vzdělávací program RVP ZV, který se vyučuje v běžných základních školách. K zavádění principů sociální inkluze vyjadřují pochybnosti z hlediska neúměrného finančního zatížení v kontextu výdajů na školství ze státního rozpočtu, z nepřipravenosti učitelů běžných základních škol pracovat s žáky s diagnózou hraničního intelektu, z organizačního chaosu a neúčinnosti výuky ve tř́dě, z blízkého časového termínu aplikování novely školského zákona do praxe, z neúčinnosti metodických nástrojů podpůrných opatření, z paradoxního důsledku prohloubení selekce ve školství předpokládaným nárůstem zakládání soukromých elitních škol, případně z traumatizování všech aktérů výuky z hromadících se problémů.

Je evidentní, že téma sociální inkluze není pouze produktem procesu školní edukace, ale má přesah do oblastí rodinné socializace, způsobů trávení volného času, trhu práce, rasové (ne)tolerance v české společnosti, sociální stratifikace v české společnosti, uznání rovných šancí, obývání veřejných prostor, úrovně sociálního zázemí, konstrukce tzv. objektivizovaného vědění (srov. Berger \& Luckmann, 1999) o životě sociálně znevýhodněných skupin obyvatel atd. Problém sociální inkluze lze nahlížet i z pohledu mocenského (ř́dicího), tedy z pohledu institucí, které budou mít realizaci a kontrolu změn na starosti. Neziskové organizace se snaží prosadit svou verzi dodržování lidských práv na podstatě inkluze. Svou kritikou tak jdou (ne)chtěně proti modelu vzdělávání na ZŠ praktických. Z důvodu systémového bojují proti sociální segregaci. Naproti tomu ze strany zástupců ZŠ praktických se jedná 
o podporu selekce založené na psychologických posudcích. Tato, diagnostikou podpořená, selekce vytváří podmínky pro diferencovanou školní socializaci ne-jenom romských dětí. Diferenciace tak utváří typ „školy na míru“ pro každého žáka. Frustrace učitelů ZŠ praktických pramení z pocitu, že suplují socializační úlohu rodičů a zároveň ještě učí. Kritiku neziskového sektoru z etnické diskriminace berou jako útok proti své práci a svému poslání. Náročnost profese je v jejich očích společností (nebo politickými špičkami) nedoceněna. Střet názorů obou táborů má zdroj v pohledu na řešení problému edukace žáků ze sociálně znevýhodněného prostředí, resp. žáků se specifickými vzdělávacími potřebami. Mediálně je vytvářen nesmiřitelný konflikt mezi sektory, kterým jde vlastně o podobnou vizi, tedy o sociální spravedlnost a rovné šance na vzdělání. Důležitým aspektem odlišného vidění sociální reality je rozdílnost ve zkušenostní praxi aktérů (autorů článků v UN) a také v institucionálním nárůstu subjektů participujících na regulaci zmíněné edukace romských žáků. Dochází tak i ke srovnávání s předchozím politickým (totalitním) režimem. Například starší aktéři vzpomínají na dobu totality, kdy bylo vzdělávání hrazeno a řízeno výhradně státem, a považují tuto úlohu státu za žádoucí. Připomeňme, že v době totality byla propagována selekce dětí podle intelektu. V neziskovém sektoru zpravidla působí lidé, kteří svou úlohu spatřují v prosazování principů subsidiarity a sociální inkluze, tedy v omezení státních či centralizovaných intervencí.

Týdeník UN zastává názory z pohledu pedagogických a psychologických aktérů, kteří prosazují dvoukolejnost českého školství. Touto neskrývanou orientací logicky předkládá čtenářưm argumenty v relativně jednostranném hodnoticím kontextu. Nezanedbatelný vliv sehrává i vymezení odborníků na edukaci dětí se specifickými vzdělávacími potřebami z pohledu přispěvatelů UN. Konkrétně se zaměřuje na působnost speciálních pedagogů, kteří prioritně vzdělávají děti se zdravotním postižením. Je zvláštní, že názory sociálních pedagogů, kteří se orientují na žáky v ústavní výchově nebo na žáky ze sociálně znevýhodněného prostředí (zvláště na romské žáky), nemají v UN zastoupení.

Výhodou diskursivní analýzy je její zaměření i na to, co vysloveno či napsáno nebylo, ale je součástí diskursivního pole. Ono skryté (nevyřčené) může vycházet ze skutečnosti, že sociální pedagog se orientuje na vzdělávání dětí ze sociálně znevýhodněného prostředí a svými intervencemi má blízko k činnosti neziskového sektoru. Kritérium mentálního nebo tělesného postižení dítěte u něj není, na rozdíl od speciálního pedagoga, zásadní. Na rozdíl 
od kritizované akademické neodbornosti činovníků v neziskovém sektoru (očima autorů ze speciálněpedagogického tábora přispívajícího do UN se jedná o diletanty) může mít sociální pedagog bud' bakalářský, nebo magisterský akademický titul. Nicméně o edukaci žáků ze sociálně znevýhodněného prostředí referují v tomto týdeníku zástupci neziskových organizací, ČŠI nebo zástupci Úřadu vlády ČR. Edukace dětí se specifickými vzdělávacími potřebami je zde konstruována jako resort speciálních pedagogů, psychologů a poradenských pracovníků. Tato skutečnost se promítá do tvorby diskursivního pole, ve kterém zástupci tábora speciálních pedagogů v UN řeší zejména podmínky edukace dětí s LMP, případně dětí se středním nebo s těžkým mentálním postižením a $\mathrm{s}$ jinými tělesnými postiženími ve vztahu k novele školského zákona. Podmínky edukace romských žáků ve vztahu k novele školského zákona jsou těmito zástupci nazírány prizmatem neoprávněně zveličované diskriminace.

Na závěr se vrat'me k východisku diskursivní analýzy, a to ke konstruktivistickému pojetí utváření sociální reality (Berger \& Luckmann, 1999). Na utváření kulturně-sociálních vzorců každodenního vědění u různých sociálních skupin má silný vliv mediální produkce (Thompson, 2004). Kulturně-sociální kontext čtenáře promítnutý do jeho kulturního kapitálu se podílí na zvýznamňování obsahu textu. Čtenář ve své žité každodennosti ukotvené v sociálním řádu vychází při zpracování informací (symbolických sdělení) ze své aktuální zásoby vědění. On-line dostupnost mediálních obsahů UN v čase a v prostoru oslovuje různé čtenáře ze sociálně diverzifikovaného prostředí, kteří si význam konstruují do své „soukromé“ sféry vědění a podle toho i jednají. Čtenář sice dokáže mediální obsahy kriticky dekonstruovat, nicméně úroveň jeho dekonstrukce je mj. závislá na př́istupu ke zdrojům moci, na dosaženém vzdělání, na ochotě kriticky zkoumat předkládané informace atp. Z výše popsaného výkladu vyplývá poznatek, že ten, kdo produkuje mediální sdělení, zároveň produkuje názory veřejného mínění. Školské instituce předávají vědění, čímž disponují symbolickou mocí, která ovlivňuje způsoby produkce a př́ijmu těchto obsahů. Média rovněž produkují symbolickou moc informováním o tzv. realitě a svou masovostí ovlivňují veřejné mínění. Spousta př́jemců považuje mediálně prostředkovanou realitu za pravdivou, obdobně funguje i působení obsahů školského kurikula na žáky. Právě tento poznatek o symbolické institucionální moci médií a školy můžeme považovat za podnětný faktor pro tvorbu diskursivních analýz. 


\section{Literatura}

Austin, J. L. (2000). Jak udělat něco slovy. Praha: Filosofia.

Berger, P., \& Luckmann, T. (1999). Sociální konstrukce reality. Pojednání o sociologizaci vědění. Brno: Centrum pro studium demokracie a kultury.

Dreyfus, H. L., Rabinow, P., \& Foucault, M. (2002). Za hranicemi strukturalismu a hermeneutiky. Praha: Herrmann a synové.

Fónadová, L. (2014). Nenechali se vyloučit: sociální vzestupy Romů v české společnosti. Brno: Masarykova univerzita.

Gabal, I., Čada, K., \& Snopek, J. (2008). Klíč k posílení integrační politiky obcí: sociální vyloučení Romů a česká společnost. Praha: Otevřená společnost.

Gulová, L. (2010). Analýza vzdělávacích potřeb romských žákủ. Brno: Masarykova univerzita.

Gulová, L., \& Šíp, R. (Eds.). (2013). Výzkumné metody v pedagogické praxi. Praha: Grada.

Hoffmannová, J., \& Müllerová, O. (2000). Jak vedeme dialog s institucemi. Praha: Academia.

Homoláč, J. (2009). Internetové diskuse o cikánech a Romech. Praha: Karolinum.

Jarkovská, L. (2013). Gender před tabulí: etnografický výzkum genderové reprodukce $v$ každodennosti školní třídy. Praha: Sociologické nakladatelství.

Jarkovská, L., Lišková, K., Obrovská, J., \& Souralová, A. (2015). Etnická rozmanitost ve škole. Stejnost v různosti. Praha: Portál.

Katrňák, T. (2003). Otázky sociální inkluze romské komunity. Brno: Masarykova univerzita.

Katrňák, T. (2004). Odsouzeni k manuální práci: vzdělanostní reprodukce v dělnické rodině. Praha: Sociologické nakladatelství.

Keller, R. (2007). Diskursforschung. Wiesbaden: Verlag für Sozialwissenschaften.

Klapko, D., Remsová, L., Kolaříková, V., Sedláková, M., \& Žákovský, L. (2014). Výzkumný exkurz do diskursů o Romech. Brno: Masarykova univerzita.

Navrátil, P. (2003). Romové v české společnosti: jak se nám spolu žije a jaké má naše soužití vyhlídky. Praha: Portál.

Nekvapil, J. (1999-2000). Etnometodologická konverzační analýza v systému encyklopedických hesel. Češtinář, 1999-2000(3), 80-87.

Nekvapil, J., \& Leudar, I. (2002). Sekvenční struktury v mediálních dialogických sítích. Sociologický časopis, 38(4), 483-500.

Němec, J. (2010). Edukace romských žáků v zrcadle výzkumných šetření. Brno: Masarykova univerzita.

Potter, J., \& Wetherell, M. (2004). Discourse and social psychology. Beyond attitudes and behaviour. London: Sage.

Röhrich, A. (2008). Ideologie, jazyky, texty: analýza a interpretace textů Rudého práva z roku 1953 a 1975 a Práva z roku 1997. Liberec: Bor.

Sacks, H. (1992). Lectures on conversation. Cambridge: Blackwell.

Šanderová, J., \& Šmídová, O. (2009). Sociální konstrukce nerovností pod kvalitativní lupou. Praha: Sociologické nakladatelství.

Šmídová, O. (2013). "Rudé právo psalo, že nás bylo málo...": restituce identity a identita restituce $v$ diskursu Rudého práva v roce nula. Praha: Sociologické nakladatelství.

Šotolová, E. (2011). Vzdělávání Romů. Praha: Karolinum. 
Thompson, J. B. (1990). Ideology and modern culture. Cambridge: Polity Press.

Thompson, J. B. (2004). Média a modernita: sociální teorie médií. Praha: Karolinum.

Vojtíšková, K., Matějů, P., Straková, J., \& Veselý, A. (2011). Nerovnosti ve vzdělávání. Od měření $k$ řešení. Praha: Sociologické nakladatelství.

Wodak, R., \& Meyer, M. (2009). Methods of critical discourse analysis. London: Sage.

Zábrodská, K. (2009). Variace na gender: poststrukturalismus, diskurzivní analýza a genderová identita. Praha: Academia.

\section{Autor}

Mgr. Dušan Klapko, Ph.D., Masarykova univerzita, Pedagogická fakulta, Katedra sociální pedagogiky, Poříčí 31, Brno 602 00, e-mail: klapko@ped.muni.cz

\section{Overlying discourses of power in the weekly newspaper Učitelské noviny: Social inclusion of Roma pupils in Czech education}

Abstract: This paper deals with the analysis of discourse concerning the education of Roma pupils as pupils with a social disadvantage or of pupils with specific educational needs. The analysis is focused on the discourses creating school reality as presented in the weekly newspaper Učitelské noviny. The interpretation is viewed in context with the School Law amendment addressing social inclusion. Concerning research methodology, the investigation made use of discourse analysis. In our research we analysed the speakers' discourse positions, listed discourses of power, described the structures of the socially disadvantaged background of Roma pupils and examined the strategies the speakers use to construct their social reality.

Keywords: discourse of power, Roma pupil, Practical School, social inclusion, discourse analysis 